Thorax (1973), 28, 729.

\title{
The Feyrter cell in hypoxia
}

\author{
HOMEIRA MOOSAVI, PAULSMITH, and \\ DONALD HEATH
}

The Department of Pathology, University of Liverpool

\begin{abstract}
Moosavi, H., Smith, P., and Heath, D. (1973). Thorax, 28, 729-741. The Feyrter cell in hypoxia. It is clear that the bronchial tree has functions beyond the mere conduction of air into the alveolar spaces. In addition to the familiar ciliated respiratory epithelial cells the bronchus is lined by non-ciliated Clara and Feyrter cells. In the present study we investigated the histological and ultrastructural features of the bronchial argyrophilic (Feyrter) cell of the neonatal rat. On electron microscopy this cell has all the features of an APUD cell which is associated with the secretion of polypeptide hormones. It bears a close ultrastructural resemblance to the chief cell of the carotid body and shows the same changes in its membranebound bodies on exposure to chronic hypoxia. These are strong grounds for believing that the bronchi and bronchioles have either a chemoreceptor or an endocrine function in the neonatal period.
\end{abstract}

The bronchial tree appears to have functions beyond the mere conduction of air into the alveolar spaces. The most familiar cell lining the bronchus is the ciliated respiratory epithelial cell (Fig. 1) but other non-ciliated cells are to be found there. One is the Clara cell considered by some to be the source of pulmonary surfactant (Fig. 1). Another is capable of reducing silver salts in the presence of a weak reducing agent and hence is termed argyrophilic. It is sometimes called the Feyrter cell after the Austrian pathologist who was one of the first to study it (Feyrter, 1951, 1954). He thought the cell might be part of an endocrine system with widespread distribution throughout many organs including the lungs. Indeed it has electron microscopic features of so-called APUD cells (a term which we explain below), which are commonly associated with secretion of polypeptide hormones (Pearse, 1969). Furthermore, it has an ultrastructure virtually identical with that of the chief cell of the carotid body. Previous studies (Arias-Stella, 1969; Heath, Edwards, and Harris, 1970; Edwards, Heath, and Harris, 1971a; Edwards, Heath and Harris, 1972; Edwards et al., 1971b; Heath, Edwards, Winson, and Smith, 1973) have shown that in states of chronic hypoxia the carotid bodies enlarge and show characteristic ultrastructural changes. For these reasons we set out to determine if hypoxia produces the same electron microscopic changes in the Feyrter cell.

Requests for reprints: Professor D. Heath, Department of Pathology, University of Liverpool

\section{MATERIAL AND METHODS}

Two experiments were performed. The purpose of the first was to establish the histological and ultrastructural features of the Feyrter cell. The aims of the second were to study the effects of hypoxia on these cells and to determine any changes in the incidence of Feyrter cells from neonatal life to maturity.

EXPERIMENT 1 Six Wistar albino rats were killed by intraperitoneal injections of $0.5 \mathrm{ml}$ of pentobarbitone sodium when they were 3 days old. The thorax was opened and two blocks of lung were resected. One block was taken through the left hilum and the left lung at right angles to the longitudinal axis of the left main bronchus so that the bronchus was obtained in transverse section. A second block was taken through the inferior lobe of the right lung to include the right hilum; in this the bronchi were also obtained in transverse section. Before immersing these blocks of fresh tissue in fixative for subsequent light microscopy, a thin slice was taken from the block of left hilum and lung. Fragments of tissue were cut from the hilar portion of this thin slice with a razor blade and were fixed immediately in ice-cold glutaraldehyde for subsequent electron microscopy. The remainder of the left block of tissue and the whole of the right block were immersed in Bouin's solution, a fixative which is preferable for the later demonstration of argyrophilia. After three days the fixed lung tissue was embedded in paraffin wax. Five stepped sections, $100 \mu \mathrm{m}$ apart and $5 \mu \mathrm{m}$ in thickness, were cut from each block and stained by Jabonero's ammoniated silver carbonate technique as modified by van Campenhout for the demonstration of argyrophilia. In all instances control sections of appendix and 


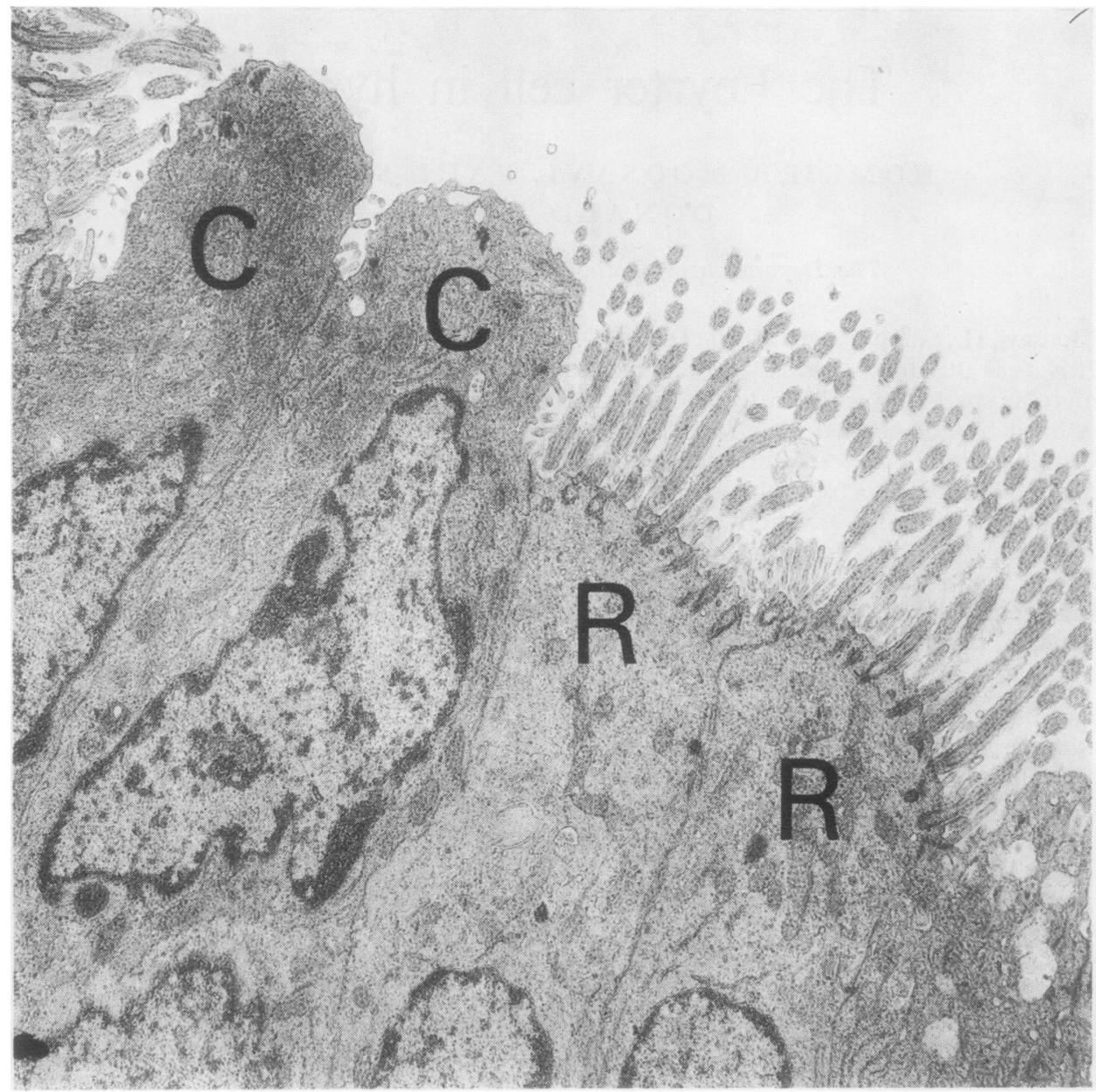

FIG. 1. Electron micrograph of bronchial epithelium from a rat showing two ciliated respiratory epithelial cells $(R)$ and two non-ciliated Clara cells $(C) .(\times 7,500)$

adrenal medulla were stained at the same time. Fixation in Bouin's solution while suitable for the demonstration of argyrophilia is not satisfactory for other staining techniques.

EXPERIMENT 2 Sixteen 4-day-old Wistar albino rats were divided into a group of four test rats and 12 controls. All the animals were weighed at the beginning of the experiment. The test rats were housed with their mother in one cage, and the control rats were kept in groups of four with their mothers in three other cages. The mother rats were provided with food and water and placed together with their offspring in a hypobaric chamber (Fig. 2). The atmospheric pressure within the chamber was slowly reduced to $380 \mathrm{mmHg}$ over a period of one hour. This simulates an altitude of 18,000 feet $(5,488 \mathrm{~m})$ above sea level. The test and four of the control animals were killed by intraperitoneal injections of $0.5 \mathrm{ml}$ of pentobarbitone sodium after 20 hours. Thereafter control rats were killed twice weekly so that the experiment ended after a month. The same procedures as were used in the first experiment were employed in the second.

A qualitative investigation was carried out on the $\mathscr{\gamma}$ occurrence of argyrophil cells in the bronchi and $\theta$ terminal bronchioles. In the rat, bronchi and terminal bronchioles have smooth muscle in their wall $\stackrel{\mathcal{S}}{?}$ but whereas the former are lined by ciliated respira- $T$ tory epithelium the latter are lined by cuboidal $\bar{O}$ epithelium. We found it very difficult to detect the point of transition from one type of epithelium to the other so we considered bronchi and terminal bronchioles together in this study. 


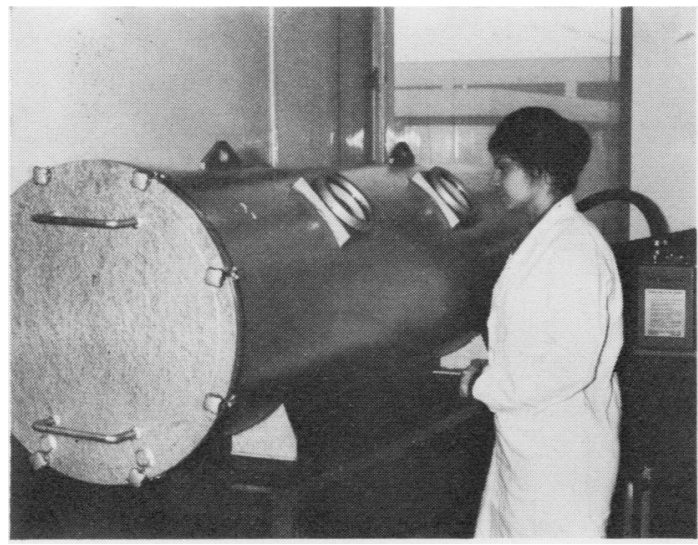

FIG. 2. The hypobaric chamber used for exposing the rats to reduced barometric pressure. Note the observation windows.

Paraffin sections, $5 \mu \mathrm{m}$ in thickness, were cut from 10 blocks of lung tissue in each animal. The sections were stained to demonstrate argyrophilia as described above. The average number of Feyrter cells per centimetre of bronchial epithelium was calculated by counting their total number in all airways in the sections. The sections were then projected on to a sheet of paper and the image of the epithelium of bronchi and terminal bronchioles was outlined. The total length of these outlines was measured by a rotometer and calibrated using the projected image of a stage micrometer. The total number of Feyrter cells was then divided by the total length of bronchial and terminal bronchiolar epithelium to obtain the average number of cells per centimetre. The number of Feyrter cells in respiratory bronchioles was not considered.

\section{QUALITATIVE RESULTS}

LIGHT MICROSCOPY IN CONTROL ANIMALS In sections stained by the van Campenhout technique Feyrter cells (Fig. 3) appear cuboidal or columnar and contain fine argyrophilic granules. They are usually exposed to the lumen of the airway and lie on the basement membrane. The nucleus is oval or round and is located in the base of the cell. Sometimes two or more Feyrter cells occur very close together. In human newborns these cells are triangular in shape and are immediately adjacent to the epithelial basement membrane (Fig. 4). They do not reach the bronchial lumen in man (Lauweryns and Peuskens, 1969; Lauweryns, Peuskens, and Cokelaere, 1970). The argyrophilic granules of Feyrter cells are larger in man than in the rat, being coarser, more tightly packed together, and basally located.

ELECTRON MICROSCOPY IN CONTROL ANIMALS. The Feyrter cell is cuboidal or columnar (Fig. 5). It is

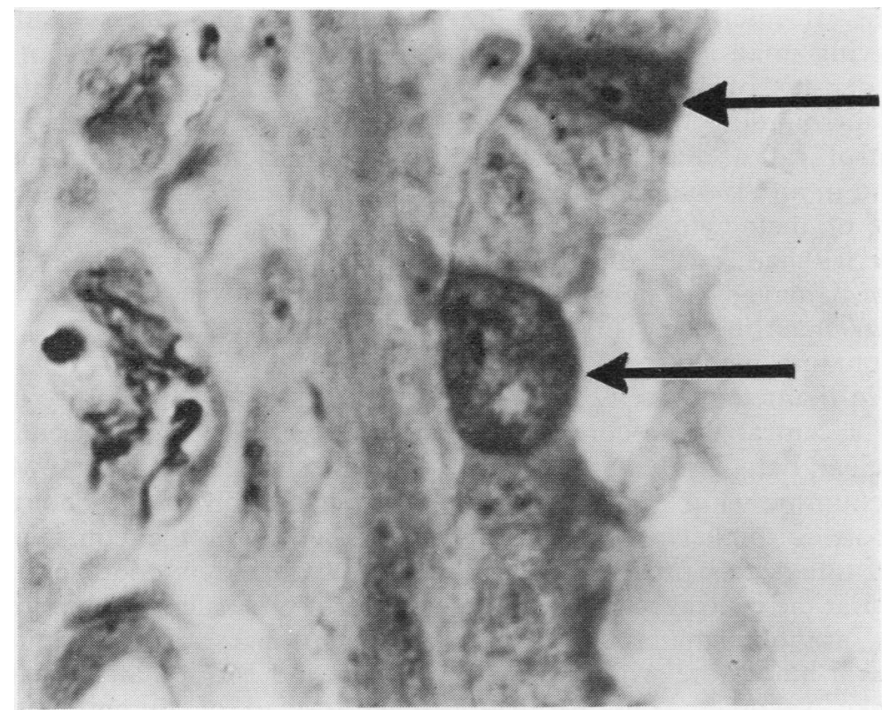

FIG. 3. Bronchial epithelium from a neonatal control rat showing two Feyrter cells (arrows) containing argyrophil granules. The cells project into the bronchial lumen and lie on the basement membrane. (Jabonero's ammoniated silver carbonate technique as modified by van Campenhout $\times 1,500)$ 


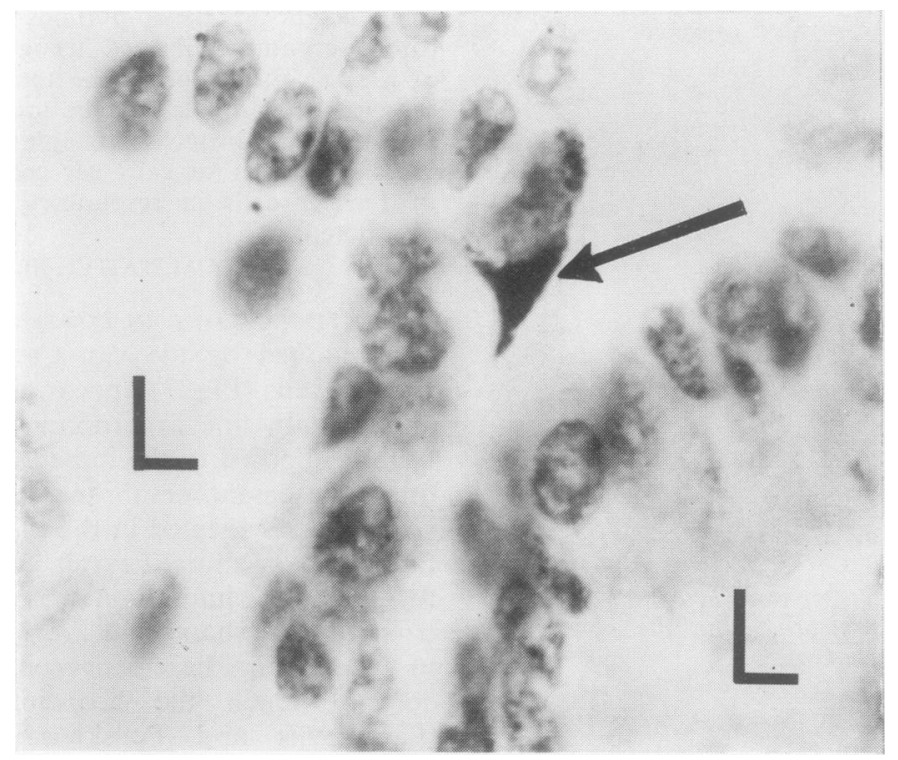

FIG. 4. Folds of bronchial epithelium from a human newborn showing a triangular Feyrter cell (arrow). The cell is adjacent to the basement membrane and does not reach the bronchial lumen (L). (Argyrophil staining as in Fig. 3) $(\times 1,500)$.

exposed to the bronchial lumen into which it presents small projections. It interdigitates with its neighbouring cells, leaving small intervening intercellular spaces. The density of its cytoplasm is similar to that of surrounding bronchial epithelium. In one control rat a cluster of seven Feyrter cells was found in an alveolar space. Most of them had lost part of their cytoplasmic membrane so that organelles had escaped into the alveolus. This group of damaged Feyrter cells was surrounded by alveolar macrophages (Fig. 6).

The Feyrter cell contains many round osmiophilic bodies ranging in diameter from 120 to 173 $\mathrm{nm}$, which consist of a central dense core and a narrow surrounding clear halo limited externally by a single unit membrane (Fig. 7). In some granules the central core is smaller and less electron dense (Fig. 8). In others this process appears to have progressed so that the central core is almost lost and replaced by granular material. At the same time the peripheral haloes are wider so that the bodies appear like vacuoles (Fig. 8). The Feyrter cell contains many mitochondria which tend to be elongated with long cristae. Both smooth and rough endoplasmic reticulum are present, the former predominating and being vesicular. Some of the cisternae of the rough endo- plasmic reticulum are wide and contain a homogeneous, structureless substance. A Golgi apparatus is seen in some of the cells. Free ribosomes are abundant. A moderate number of protein microfibrils are present. The nucleus tends to be basally located and shows a large amount of chromatin near its membrane.

LIGHT MICROSCOPY IN HYPOXIC ANIMALS. No histological changes were detected in the Feyrter cells of the test rats.

ELECTRON MICROSCOPY IN HYPOXIC ANIMALS. Pro- $\frac{D}{0}$ nounced changes were seen in the ultrastructure of the osmiophilic bodies which appeared to be $N$ an exaggeration of the changes noted in some of $N$ these bodies in the controls (Fig. 8). The peri- N pheral haloes were wide and the central cores were small and frequently excentric (B in Fig. 9). In some instances the remaining core was of low $\stackrel{O}{=}$ density and formed an ill-defined diffuse granular $\stackrel{\mathbb{D}}{\stackrel{D}{A}}$ mass instead of the previously compact central core (A in Fig. 9). In some bodies the widening of the peripheral halo was so pronounced as to trans- $\frac{\mathbb{D}}{\mathbb{D}}$ form the original osmiophilic body into a micro- $\frac{\rho}{\Phi}$ vacuole ( $\mathrm{C}$ in Fig. 10). The diameters of the altered $\triangle$ osmiophilic bodies ranged from 127 to $207 \mathrm{~nm}$. 


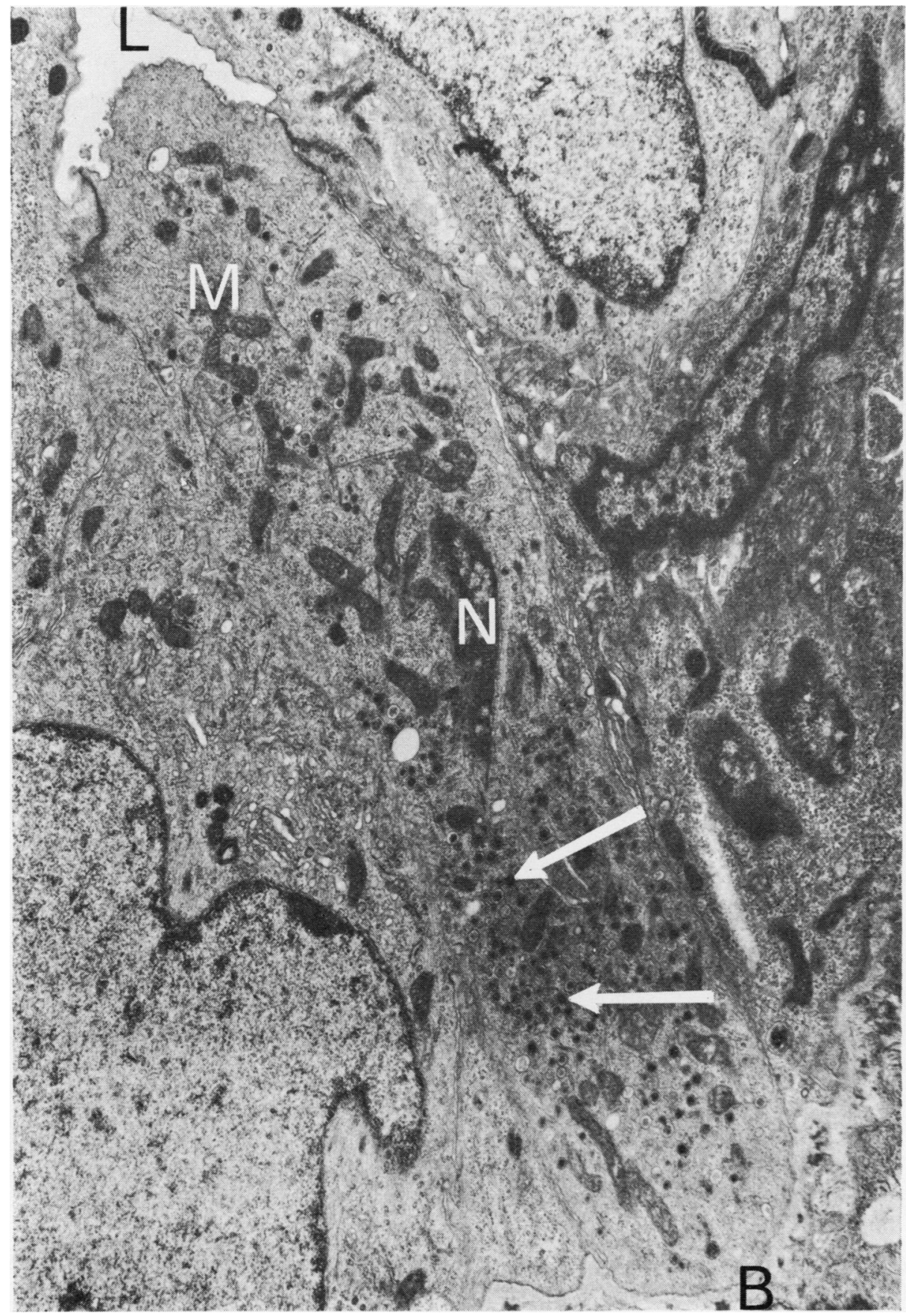

FIG. 5. Electron micrograph of bronchial epithelium from a neonatal control rat showing a Feyrter cell lying on the basement membrane $(B)$ with its tip exposed to the lumen of the bronchus $(L)$. The cell contains characteristic round osmiophilic bodies (white arrows) and the elongated mitochondria $(M)$. Only part of the nucleus $(N)$ is shown in the figure. $(\times 12,500)$. 


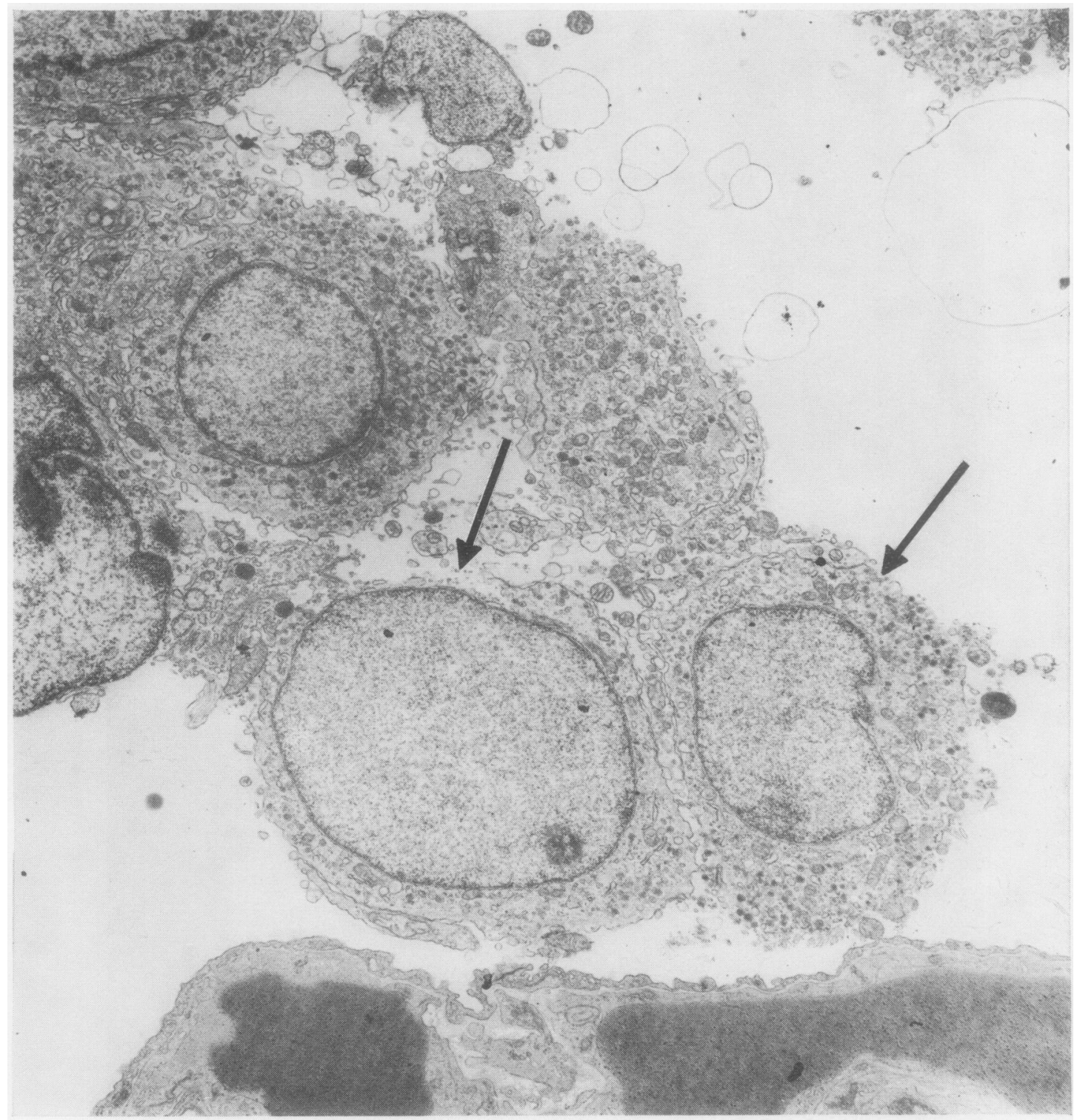

FIG. 6. Electron micrograph of a neonatal control rat showing a cluster of Feyrter cells in an alveolar space. Some have lost part of their cytoplasmic membrane (arrows) so that cytoplasmic organelles had been released into the alveolus. $(\times 7,500)$. 


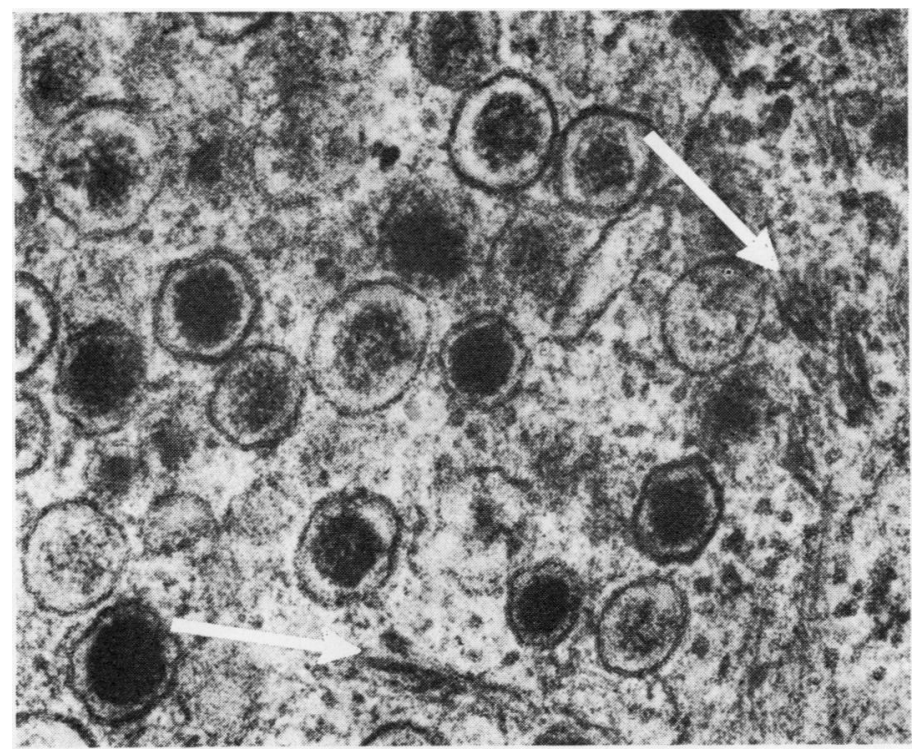

FIG. 7. Detail of Fig. 5 to show the round osmiophilic bodies with a dark central core, and a narrow peripheral light halo bounded by an outer membrane. Also seen in the cytoplasm are protein microfibrils (white arrows). Free ribosomes are seen in the background as dots. $(\times 75,000)$.

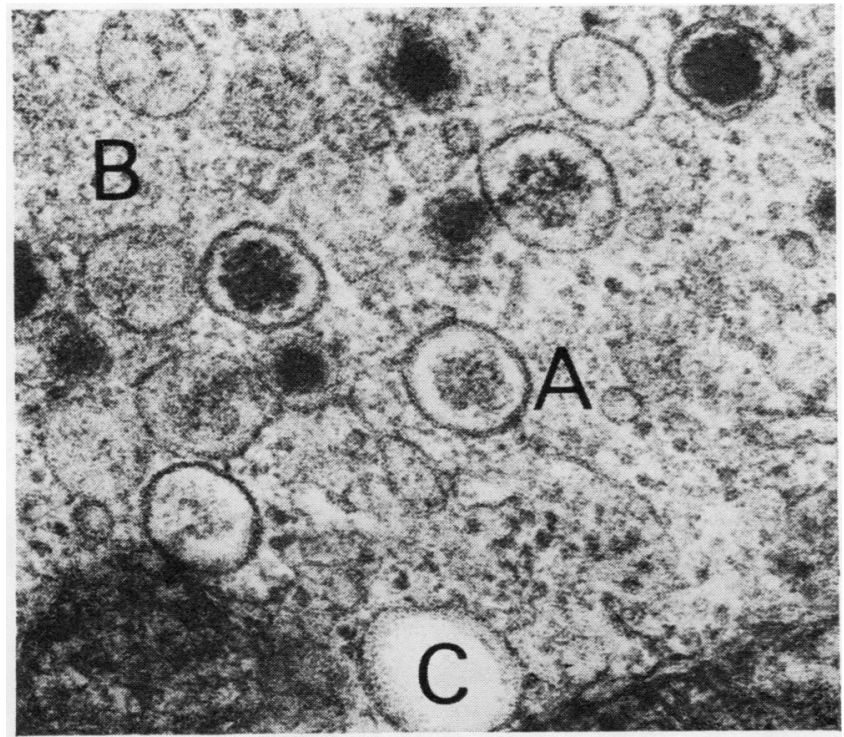

FIG. 8. Detail of Fig. 5 to show other osmiophilic bodies in the cytoplasm in which the central core is smaller and less dense $(A) ;$ in others $(B)$ the central core has been replaced by granular material. In a third group the osmiophilic body has been transformed into a small vesicle $(C) .(\times 75,000)$. 


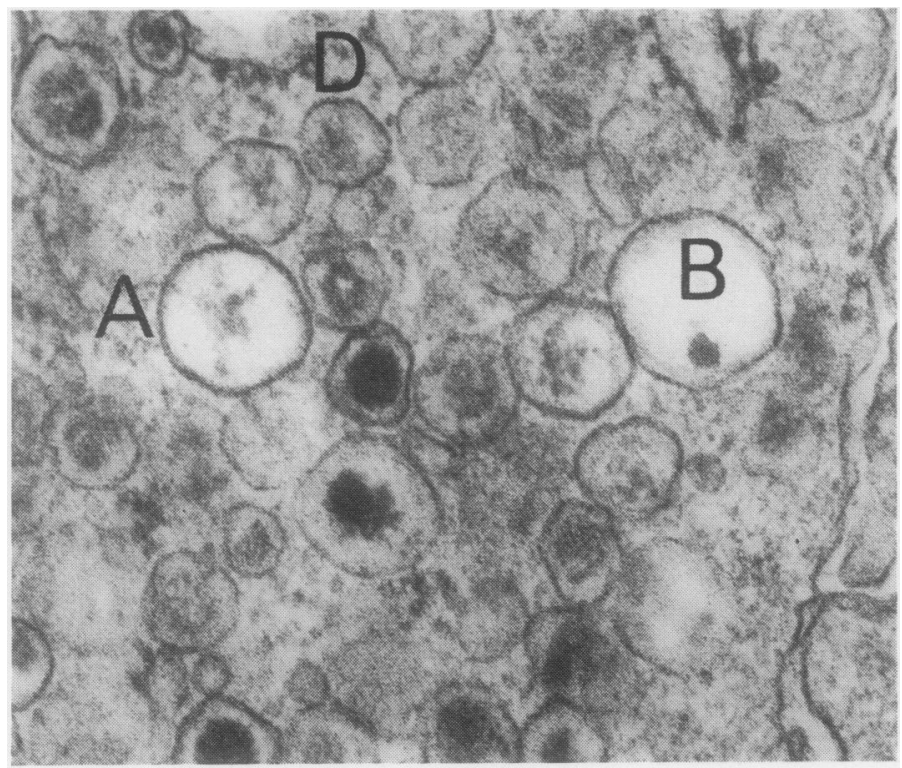

FIG. 9. Electron micrograph of part of a Feyrter cell from a hypoxic rat. In some osmiophilic bodies the central core is smaller, less dense, and excentric with widening of the surrounding halo to form a vesicle $(B)$. In other bodies $(A)$ the central core remains only as a collection of granular material. Several osmiophilic bodies show loss of limiting membrane and the contents appear to merge into the surrounding cytoplasm $(D) .(\times 75,000)$.

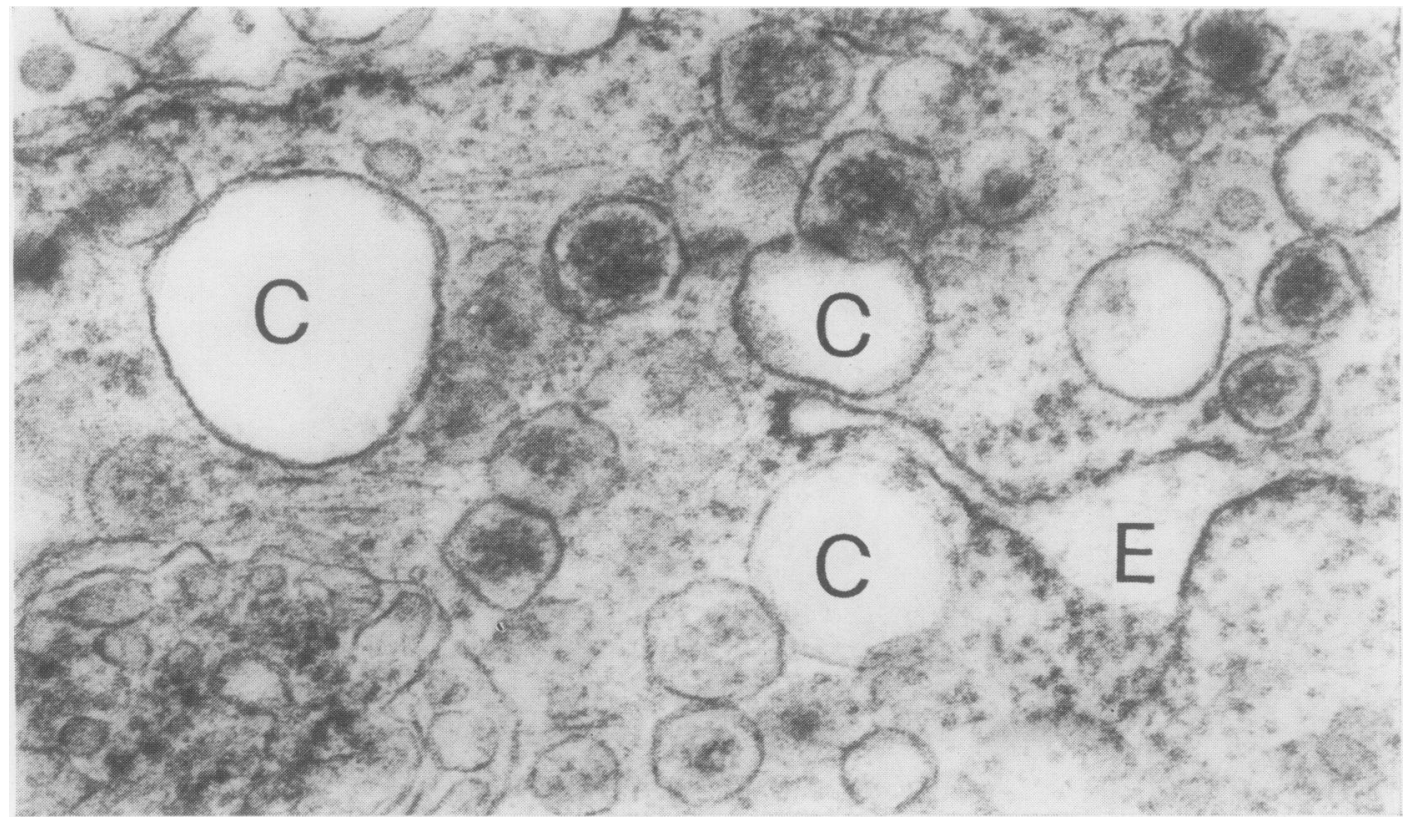

FIG. 10. A part of the same cells as in Fig. 9 showing replacement of osmiophilic bodies by microvacuoles $(C)$ and a wide cisterna of rough endoplasmic reticulum $(E) .(\times 75,000)$. 
RELATIVE \% AREA OF CORE TO GRANULE CONTROL
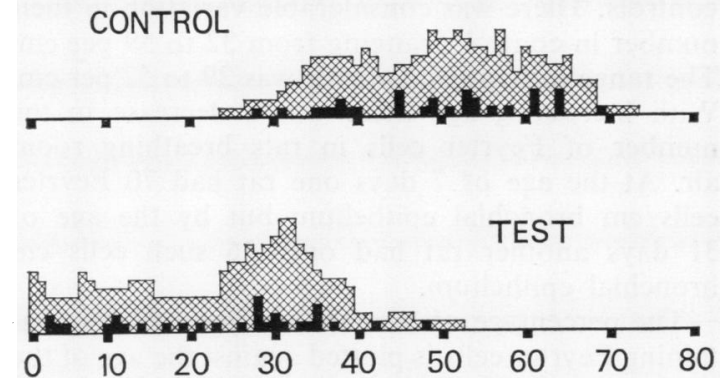

FIG. 11. Diagram to show the difference in area of central osmiophilic core relative to that of entire granules in a control and a hypoxic rat, according to the method described in the text.

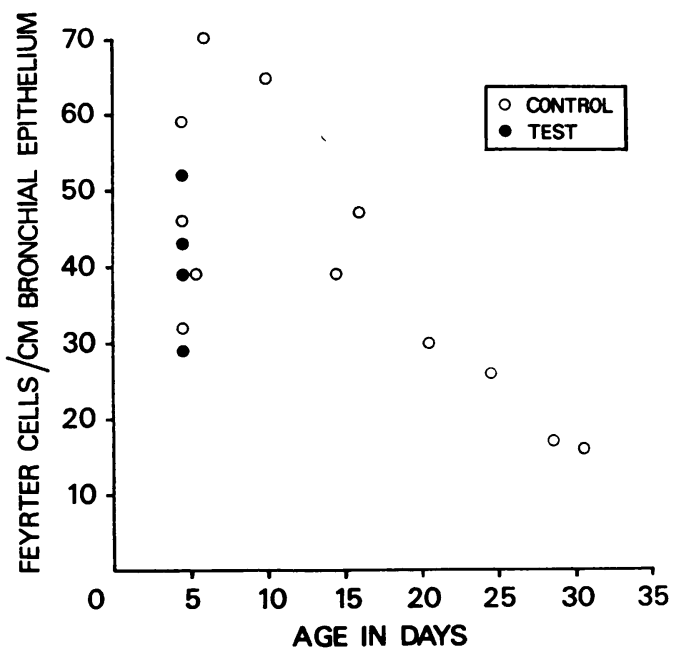

FIG. 12. Relation between the number of Feyrter cells per centimetre length of bronchial and bronchiolar epithelium in control and hypoxic rats, and age in days.

Vacuoles up to $373 \mathrm{~nm}$ in diameter were found. Occasionally part of the limiting membrane was lost so that the content appeared to merge into the surrounding cytoplasm (D in Fig. 9). Some of the cisternae of rough endoplasmic reticulum were vide and contained a structureless substance $(E$ in Fig. 10).

\section{QUANTITATIVE RESULTS}

If one assumes that the osmiophilic bodies are randomly distributed in the cell and that crosssections of them are circular, one may deduce that they are spherical. We wished to quantitate the size of the central core relative to that of the whole osmiophilic body in hypoxic and control animals.
We did this by finding the range and mean values of the diameters of the central core (1) and the whole body $\overline{(\mathrm{L})}$ in 30 osmiophilic bodies respectively from one Feyrter cell in a test rat and in one such cell in a control animal (Table). The mean diameter of the core was expressed as a percentage of that of the entire osmiophilic body (Table). The ratio, $R$, of the area of the central core to that of the whole body is given by the formula:

$\vec{R}=\left(\begin{array}{c}\overrightarrow{1} \\ \mathrm{~L}\end{array}\right)^{2} \pm \Delta R$ where $\Delta R=\frac{\overrightarrow{2}}{\overline{\mathrm{L}}^{2}}\left(\mathrm{I}-\frac{\overline{\mathbf{1}}}{\overline{\mathrm{L}}}\right) \Sigma$

Here, $\Sigma$ is the error in the measurements of $\overline{1}$ and $\overline{\mathrm{L}}$, and is taken to be $1 \mathrm{~mm}$ in all cases. The error, $\Delta \mathbf{R}$, is calculated for each osmiophilic body and it is approximately equal to \pm 0.04 in both test and control animals. A graphical representation of the results in the Table is presented as Fig. 11. In this the actual value obtained by measurement is represented by a black square but the range of possible values taking the error, $\Delta \mathbf{R}$, into account is shown by cross hatching.

As a result of this the probability is related to the height of the column of cross hatching. In Fig. 11 there is a shift to the left in the test animal showing that the relative percentage area of the central core is smaller in conditions of hypoxia. The average value of $R$ in the control animal was $49 \%(S D=11)$ but in the hypoxic rat it was only $24 \%(S D=12)$.

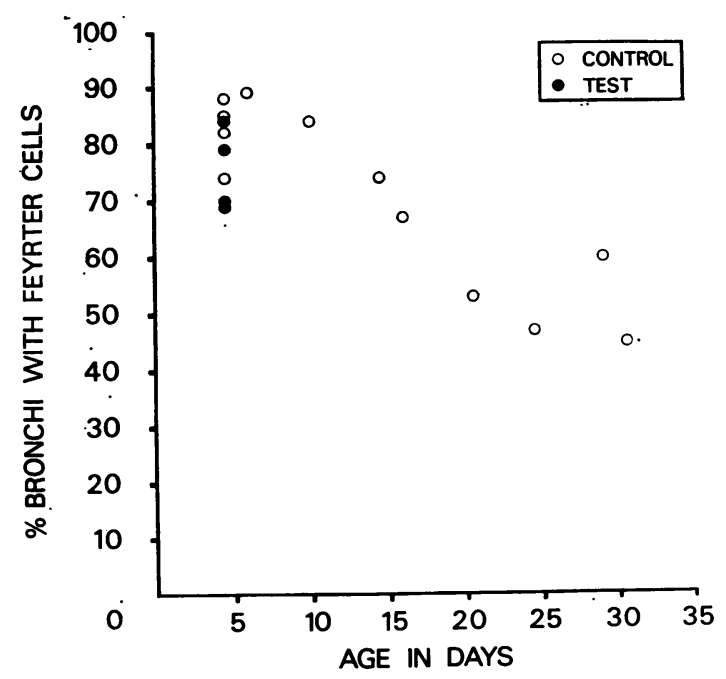

FIG. 13. Relation between the percentage of bronchi and bronchioles containing Feyrter cells in control and hypoxic rats and age in days. 
T A B L E

QUANTITATIVE DATA ON DIAMETER OF OSMIOPHILIC BODIES AND THEIR CENTRAL CORES OF FEYRTER CELLS FROM CONTROL AND TEST RATS

\begin{tabular}{|c|c|c|c|c|c|}
\hline & \multicolumn{2}{|c|}{$\begin{array}{c}\text { Diameter of } \\
\text { Osmiophilic Body } \\
\text { (nm) }\end{array}$} & \multicolumn{2}{|c|}{$\begin{array}{c}\text { Diameter of } \\
\text { Central Core } \\
(\mathrm{nm})\end{array}$} & \multirow{2}{*}{$\begin{array}{c}\text { \% Mean } \\
\text { Diameter of } \\
\text { Core } / \\
\begin{array}{c}\text { Osmiophilic } \\
\text { Body }\end{array}\end{array}$} \\
\hline & Range & Mean & Range & Mean & \\
\hline $\begin{array}{l}\text { Control } \\
\text { Test .. }\end{array}$ & $\begin{array}{l}120-173 \\
127-207\end{array}$ & $\begin{array}{l}147 \\
167\end{array}$ & $\begin{array}{l}73-120 \\
27-120\end{array}$ & $\begin{array}{r}100 \\
67\end{array}$ & $\begin{array}{l}68 \\
40\end{array}$ \\
\hline
\end{tabular}

This confirms that there was a significant statistical difference in the area of the central core in control and hypoxic animals.

The average number of Feyrter cells per centimetre of bronchial epithelium in control and test rats in the second experiment is plotted against the age in days in Figure 12. It shows that at the age of 4 days there was no significant difference between the number of Feyrter cells in hypoxic animals and $\frac{2}{\partial}$ controls. There was considerable variation in their $\overline{\frac{\sigma}{\omega}}$ number in controls, ranging from 32 to 59 per $\mathrm{cm}$. The range in hypoxic animals was 29 to 52 per $\mathrm{cm}$. ㅇ With increasing age there was a decrease in the ${ }^{\infty}$ number of Feyrter cells in rats breathing room $\vec{\circ}$ air. At the age of 7 days one rat had 70 Feyrter $\overrightarrow{\vec{H}}$ cells $/ \mathrm{cm}$ bronchial epithelium but by the age of $\stackrel{\omega}{\omega}$ 31 days another rat had only 16 such cells $/ \mathrm{cm} \underset{\times}{\vec{x}}$ bronchial epithelium.

The percentage of bronchi and bronchioles con- $\stackrel{\infty}{\mathrm{N}}$ taining Feyrter cells is plotted against the age of the rats in days in Figure 13. Once again there was no 0 significant difference at the age of 4 days between 0 test and control animals. However, there was $a_{-}$ decrease in the percentage of bronchi containing $\vec{z}$ Feyrter cells with increasing age. At the age of 70 days, $89 \%$ of the bronchi of one rat contained Feyrter cells but at the age of 31 days only $45 \%$ of the bronchi of another rat contained such cells.

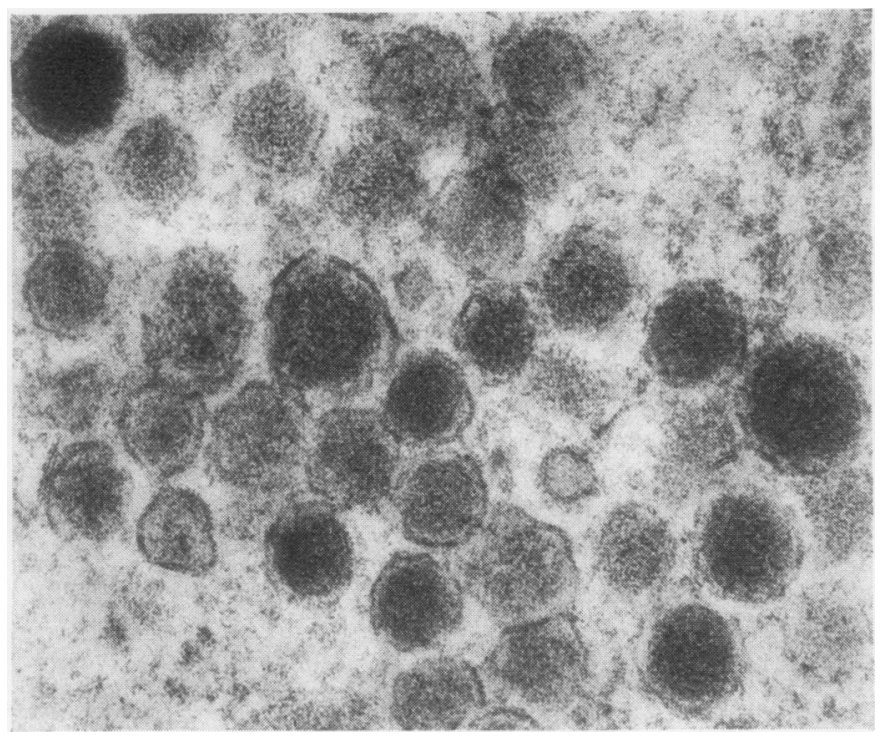

FIG. 14. Electron micrograph of part of a chief cell of carotid body from a low-altitude guinea-pig to show the round osmiophilic bodies with a dark central core and a narrow peripheral halo bounded by an outer membrane $(\times 75,000)$. 


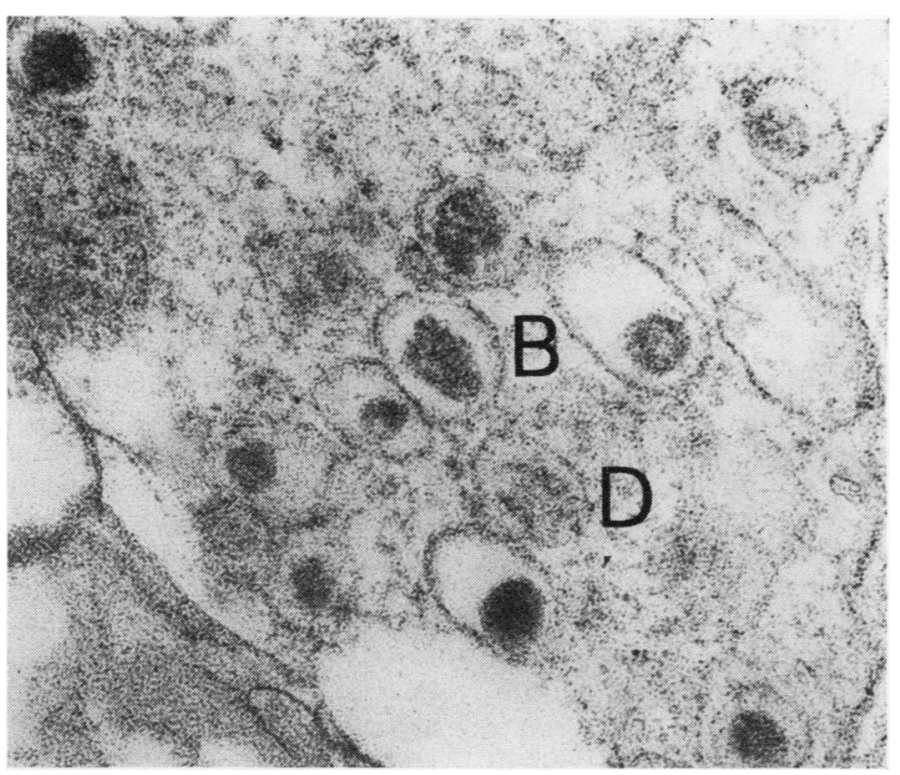

FIG. 15. Electron micrograph of part of a chief cell of carotid body from a high-altitude guinea-pig (born and bred at Cerro de Pasco, in the Peruvian Andes at an altitude of 14,250 feet above sea level) to show the smaller, less dense, and excentric central core with widening of the surrounding halo to form a vesicle (B). Several osmiophilic bodies show loss of limiting membrane so that the contents appear to merge into the surrounding cytoplasm $(D)(\times 75,000)$.

\section{DISCUSSION}

The conduction of air to the alveolar spaces is so obviously the primary function of the bronchial tree that one may accept too easily that this is its only function. Familiarity with the ciliated respiratory epithelium lining the airways should not lead one to forget the existence and function of its non-ciliated fellows, the Feyrter cells, which form the subject of this paper, and the Clara cells.

The argyrophilic Feyrter cell found in the walls of the terminal and respiratory bronchioles of neonates has the cytological and ultrastructural features of a so-called APUD cell, the name of which is derived from the first letters of some of its biochemical features such as amine content, amine precursor uptake, and decarboxylation (Pearse, 1969). Ultrastructural features of the Feyrter cell which are typical of APUD cells include the membrane-bound secretion vesicles, the preponderance of smooth endoplasmic reticulum and high content of free ribosomes, and the tendency to produce protein microfibrils.

Pearse (1969) includes as a possible member of the APUD cell family the chief cell of the caro- tid body which has ultrastructural features virtually identical with those of the Feyrter cells (Fig. 14). This similarity is of great interest since the carotid body is generally accepted as a chemoreceptor. If the identical appearances of the ultrastructure of the carotid body cells and Feyrter cells were matched by a similarity of function it would imply multiple small air chemoreceptors scattered throughout the terminal portions of the bronchial tree in newborns. The concept of an air chemoreceptor as contrasted to the more familiar blood chemoreceptor is supported by the presence of similar argyrophilic cells in the airways of birds. If Feyrter cells are chemoreceptors it appears that they are active only during neonatal life since we have shown a steady decline in their numbers during the first month of life. We have only occasionally encountered Feyrter cells in adult rats. Our observation of a clump of detached Feyrter cells (Fig. 6) suggests that they may exfoliate, or alternatively undergo metaplasia when they are no longer required. It is of considerable interest that our present study shows that ultrastructural changes occur in the Feyrter cell identical with those found in the carotid body chief cell on 
exposure to hypoxia (Fig. 15). High altitude guinea-pigs are exposed to chronic hypoxia on account of the diminished barometric pressure, and they show electron microscopic changes in the chief cells which consist of widening of the haloes of the osmiophilic bodies with the formation of microvacuoles, together with diminution in size and density of the osmiophilic core which usually becomes excentric or transformed into granular material which diffuses into the surrounding vacuole (Fig. 15). As we have seen, identical changes occur in the bronchial argyrophilic cells of neonates exposed to hypoxia. Another similarity is that both Feyrter and carotid body cells have direct contact nerve endings. Such similarities in ultrastructure could be held to support the view that Feyrter cells also have a chemoreceptor function.

Other examples of APUD cells throughout the body are endocrine, secreting polypeptide hormones. They include the $\beta$ cell of the islets of Langerhans which secretes insulin, the $C$ cell of the thyroid which produces calcitonin, the pituitary corticotroph secreting $\mathrm{ACTH}$, and the pancreatic islet $\alpha_{2}$ cell producing glucagon (Pearse, 1969). Since the electron microscopic features shared by all these endocrine cells are also found in the Feyrter cell it is possible that they too are endocrine cells capable of secreting a polypeptide hormone which Pearse tentatively terms 'pneumokinin'.

The cells in the body which stain black with silver salts due to deposits of the metal in their cytoplasm are usually classified as either 'argentaffin' or 'argyrophil'. Argentaffin cells, as exemplified by the Kultschitzky (enterochromaffin) cell of the intestine, can reduce silver salts to metallic silver because they contain powerful reducing agents such as 5-hydroxytryptamine (5-HT). Argyrophils cannot reduce silver salts on their own but require an exogenous reducing agent. It follows that argentaffin cells are also argyrophilic (Singh, 1964) but the reverse is not necessarily true. Thus the Feyrter cell is argyrophilic but not argentaffin. The functional significance of the two staining reactions is unclear.

Some believe that argyrophils are precursors of argentaffin cells on the evidence that during the development of the intestine of the chick, argyrophils appear first to be followed by argentaffin cells two days later. At first the argyrophils outnumber the argentaffin cells but this ratio drops during incubation, suggesting a development of argentaffins from argyrophil precursors (Toner, 1968). A similar embryological sequence occurs in the human intestine (Singh, 1963). Large doses of reserpine result in the liberation of 5-HT from the duodenum causing argentaffins to become argyrophil. Several days after injection the number of argyrophils becomes abnormally high followed by a similar increase in the number of argentaffin cells. This suggests that reserpine induces a hyperplasia of argyrophils which subsequently mature into argentaffins (Campbell, 1959) and that this maturation involves the production of 5-HT.

A more recent school of thought postulates that argyrophils and argentaffins are two different types of cell. This idea is based largely on histochemical differences between the two. Thus the granules of argentaffin cells show a yellow fluorescence in ultraviolet light (Campbell, 1959), they show chromaffinity and will couple with diazonium salts (Campbell, 1959), and they show a positive xanthydrol reaction (Carvalheira, Welsch, and Pearse, 1968). On the other hand, argyrophils have a positive cholinesterase reaction and a high content of alpha glycerophosphate dehydrogenase, and will take up injected L-DOPA, subsequently showing a green fluorescence after formaldehyde vapour treatment (Carvalheira et al., 1968). These are characteristics of APUD cells which are not shared by the argentaffin Kultschitzky cells. Carvalheira et al. (1968) also differentiate between argentaffin and argyrophil cells on ultrastructural grounds. They state that argyrophils are larger than argentaffin cells with larger more rounded secretory granules, more rough endoplasmic reticulum, mitochondria and free ribosomes, and that they tend to reach the intestinal lumen whereas argentaffins are basally located. We are of the opinion that most of this evidence can be applied to support either theory.

Argentaffin cells do not appear to occur in normal bronchial epithelium (Campbell, 1959; Hage, 1972; Lauweryns and Peuskens, 1969), although they are sometimes found in bronchial carcinoid tumours (Campbell, 1959; Bensch, Gordon and Miller, 1965). The argentaffin cells of the intestine secrete 5-HT capable of reducing silver salts; it has also been postulated that the bronchial argyrophilic cells may also produce amines such as histamines, catecholamines, and the kinin-generating system (Lauweryns and Peuskens, 1969). These authors believe that such compounds might be of importance in dilating the pulmonary arterial musculature of the fetus aiding adaptation to neonatal life. Another action might be to constrict bronchial smooth muscle. However, most cells containing biogenic amines are both argyrophil and argentaffin, and show a yellow fluorescence 
after treatment with formaldehyde vapour, a property shared by a small minority of bronchial argyrophil cells (Hage, 1972). The fact that these cells show a green fluorescence after injection of L-DOPA shows that they share the amine-handling properties of all APUD cells (Hage, 1972). Whether this represents the production and storage of the polypeptide hormones suggested by Pearse cannot be determined in the present state of knowledge.

Professor Heath acknowledges with gratitude the receipt of a grant from the Nuffield Foundation to support this research.

\section{REFERENCES}

Arias-Stella, J. (1969). Human carotid body at high altitudes. Item 150 in the 69th programme and Abstracts of the American Association of Pathologists and Bacteriologists, San Francisco.

Bensch, K. G., Gordon, G. B., and Miller, L. R. (1965). Electron microscopic and biochemical studies on the bronchial carcinoid tumor. Cancer, 18, 592.

Campbell, A. C. P. (1959). The pathological relationships of 5-hydroxytryptamine. In Modern Trends in Pathology, p. 231, edited by D. H. Collins. Butterworth, London.

Carvalheira, A. F., Welsch, U., and Pearse, A. G. E. (1968). Cytochemical and ultrastructural observations on the argentaffin and argyrophil cells of the gastro-intestinal tract in mammals and their place in the APUD series of polypeptide-secreting cells. Histochemie, 14, 33.

Edwards, C., Heath, D., and Harris, P. (1972). Ultrastructure of the carotid body in high-altitude guinea-pigs. Journal of Pathology, 107, 131.

(1971a). The carotid body in emphysema and left ventricular hypertrophy. Journal of Pathology, 104, 1.

, Castillo, Yolanda, Krüger, H., and AriasStella, J. (1971b). The carotid body in animals at high altitude. Journal of Pathology, 104, 231.
Feyrter, F. (1951). Zur Normung der Silberimprägnation neuraler und nichtneuraler Gewebe. Virchows Arch. für pathologische Anatomie und Physiologie, 320, 551.

_ (1954). Zur Pathologie des argyrophilen Helle-ZellenOrganes im Bronchialbaum des Menschen. Virchows Archiv für pathologische Anatomie und Physiologie und für keinische Medizin, 325, 723.

Hage, E. (1972). Endocrine cells in the bronchial mucosa of human foetuses. Acta pathologica et microbiologica Scandinavica, 80A, 225.

Heath, D., Edwards, C., and Harris, P. (1970). Post-mortem size and structure of the human carotid body. Thorax, 25, 129.

- - Winson, M., and Smith, P. (1973). Effects on the right ventricle, pulmonary vasculature, and carotid bodies of the rat of exposure to, and recovery from, simulated high altitude. Thorax, 28, 24.

Lauweryns, J. M., and Peuskens, J. C. (1969). Argyrophil (kinin and amine producing?) cells in human infant airway epithelium. Life Sciences, 8, 577.

$\longrightarrow$, - $\longrightarrow$, and Cokelaere, M. (1970). Argyrophil, fluorescent and granulated (peptide and amine producing?) AFG cells in human infant bronchial epithelium. Light and electron microscopic studies. Life Sciences, 9, 1417.

Pearse, A. G. E. (1969). The cytochemistry and ultrastructure of polypeptide hormone-producing cells of the APUD series and the embryologic, physiologic and pathologic implications of the concept. Journal of Histochemistry and Cytochemistry, 17, 303.

Singh, I. (1963). The prenatal development of enterochromaffin cells in the human gastro-intestinal tract. Journal of Anatomy, 97, 377.

(1964). On argyrophile and argentaffin reactions in individual granules of enterochromaffin cells of the human gastro-intestinal tract. Journal of Anatomy, 98, 497.

Toner, P. G. (1968). Cytology of intestinal epithelial cells. In International Review of Cytology, vol. 24, pp. 233-343. edited by G. H. Bourne and J. F. Danielli. Academic Press, New York and London. 